\section{Employment Specialist}

\author{
Allen N. Lewis, $\mathrm{Jr}^{1}$ and Pamela H. Lewis ${ }^{2}$ \\ ${ }^{1}$ School of Health and Rehabilitation Science, \\ University of Pittsburgh, Pittsburgh, PA, USA \\ ${ }^{2}$ Department of Rehabilitation Counseling, \\ School of Allied Health Professions, Virginia \\ Commonwealth University, Richmond, VA, USA
}

\section{Synonyms}

Employment coach; Job coach; Job development specialist; Job placement specialist; Vocational specialist; Work specialist

\section{Definition}

A provider or facilitator of services in the work context and community to locate and secure support options for persons with disabilities for the purpose of optimizing full career potential. Employment specialists function as a consultant and work in partnership with others to build on existing supports or develop new supports that meet individualized needs in maximizing career potential.

Employment specialists are primarily responsible for providing or securing an assessment of the person with the disability, job development,

The authors are not related by blood or marriage job placement, jobsite training, and ongoing follow along services. The goal of an employment specialist is to train the person with the disability to perform and be successful on the job and then gradually fade out of the picture over time. Employment specialists have the ultimate goal of assisting individuals with disabilities to obtain and succeed in work settings of the person's choice.

\section{Cross-References}

\author{
Job Coach \\ - Supported Employment
}

\section{References and Readings}

Blanck, P. D. (2000). Employment, disability, and the Americans with disabilities act: Issues in law, public policy, and research. Evanston: Northwestern University Press.

Griffin, C., Hammis, D., \& Geary, T. (2007). The job developer's handbook: Practical tactics for customized employment. Baltimore: Paul H. Brookes Publishing Co.

Unger, D., Kregel, J., Wehman, P., \& Brooke, V. (2002). Employers' views of workplace supports: VCU charter business roundtable' national study of employers' experiences with workers with disabilities. Richmond: VCU RRTC on Workplace Supports and Job Retention Monograph.

Wehman, P., Inge, K. J., Revell, W. G., \& Brooke, V. A. (2006). Real work for real pay: Inclusive employment for people with disabilities. Baltimore: Paul H. Brookes Publishing Co. 